\title{
Global Noir: An Introduction
}

\author{
Gray Kochhar-Lindgren
}

The history of the crime story is a social history, for it appears intertwined with the history of bourgeois society itself.

$\sim$ Ernest Mandel, Delightful Murder

Global Noir is noise, waiting, jolting, silence, speed, and smog. It is a bullet train disappearing into a tunnel. It is the shadowed intersection where the broken streetlight buzzes and where film, fiction, capital, and a cultural tonality crisscross the hyper-urban imaginary of this staccato moment of nuclear, nano, genomic, and digital globalization. Money has become electric and it shocks. It hollows out Detroit and skyscrapers arise in Guangzhou.

There are no speed limits here and behind all the business of the sound and the fury, there is an almost preternatural quiet, a low heat-generating hum from the terrestrial and near-earth cloud-networks that infiltrate our bodies with constant signals from the satellites, mobile antennae, and the massive server farms that spring from the plains in the middle of nowhere. Noir is watching and being-watched, being-shadowed. Noir is the desolation that we all crave.

In this cluster of essays, we have asked how we can philosophically reconceptualize the concept of noir, how we can crosshatch noir with the nuanced shades of history, how fiction and film screen (as both projective and protective surface) violence, and what contours the political-economy of noir is taking as it globalizes. What is noir in the age of phantomenolgy? How can we unfold the blackness and put it to work? Such questions lure us down dark alleyways, into dilapidated hotels and cafés full of smoke, but this is a digitized world of the always-on.

Global Noir, as these authors conceive of its multiplicities, is the Hong Kong produced film of Broken Tooth's misadventures in Macau and the rise of a new casino economy in that city that is so difficult to politically categorize. It is the Unidentified Narrative Object that addresses the squalid violence of the Camorra in southern Italy (and "Naples," with its Mediterranean coastline and its porous borders, has spontaneously emerged as a connective figure across these essays). Noir is a new geoaesthetic space that opens up to "anothernesses" and redefines the genre of all those murderous plots that move from a to $\mathrm{z}$ and thereby resolve the crime with a moment of explanatory repetition. (The world, however, no longer moves in the direction of such "classical" plots.) Noir speaks a cacophony of languages, including Spanish, Cantonese, Putonghua, Portuguese, Japanese, French, British, and American. Noir is the past-in-the-present and has always already appeared in the rain-splashed ruins of New York or Djemila, in the colonial cities that spawn the network of finance capitalism. The plague is let loose.

Noir is formula and stereotype, nothing but kitsch. Noir is discovery, stepping through to the other side of the mirror. On the streets of Hong Kong, cardboard collectors strain to push flatbed carts up the hill and are reflected in the opaque windows of Chase, Citigroup, HSBC, and the Bank of China. There is crime on Wall Street and in Washington, in Delhi and Shanghai, in Lagos and J'burg, in Macau and Vegas, in Havana and Buenos Aires, in Tel Aviv and Damascus, in London and Frankfurt.

Noir takes a smoky shape under dictators; noir speaks to trauma. It travels the networks of migration, mobile phones, Predators and Reapers, and all of us who are trying to stay afloat in the currencies that float, don't float, or take the plunge. Iceland is the site of global noir; Dublin, Madrid, and Athens are imploding. Pandemics spread as parasites hitch rides on sweaters, ships, and planes, as viruses and worms spread like the plague on captured hardware. Madoff, Stuxnet, and Abbottabad are coming soon to a theater in your living room, live and in color on a flat-screen TV.

In the cities of global night, there are dead-ends, broken contracts, button men, and hookers. There are white 
collars and white limousines. Dirty dollars and dirty yuan are laundered daily in the banks of the world as they travel at the speed of swoosh: here, then gone. There are dirty cops and dangerous dames. There is no there there and there is no here here, but you can buy noir at every airport kiosk.

All around the mulberry bush. Flash bulbs, flash drives, flash crash.

Global Noir is as smooth as undulating black silk and as disturbing as the scent of a woman on the hunt. Noir is high fashion that hides its origins, its derivatives, and its futures as it covers its tracks with glossy pics, leather boots, and wraparound shades. Black SUVS prowl the streets of every capital. Noir is cool. Noir is cooler than cool; it is the coolness of cool. Noir kills.

Noir has its histories, its wars and parasites, its depressions of boom and bust, its thievery of capital and the capital crimes of heads of states and heads of companies. Noir swindles, promising goods it can't deliver. It wants to keep everything for itself and double-cross its friends. But then there's always the one who keeps justice in view, or at least a certain cynical fairness, the private eye who doesn't know it all but usually knows just enough. Or, perhaps, that figure, too, is dissolving in the black rain of nuclear fallout and credit swaps.

Noir is history as it flickers across the stages of its own media platforms. First there is the screen of print: magazine, newspaper, pulp, dime novels. Poe, Doyle, Hammett, Himes, Chandler, Thompson, Cain. Smart guys, then the tough guys; this is a private dick's game, a man's thing. The dames, like the houses up in the canyons and all the city's cul-de-sacs, are lethal. Then the dames start thinking, too, become the rough-and-tumble ones to bring the bacon home. Now the guys and gals are everywhere and the picaresque hero(ine) is returning to roam the streets of Seattle or Salerno.

A car with its burning headlights speeds along a dark highway out of the 1940s and heads straight for us. It roars through all that desolate loneliness of the American West and the American city-New York, Chicago, LA—and leaps right off the screen into an algorithm of computer code. The platform is once again transmogrifying. We are being-digitized. Print continues; film continues; but now everything is occurring on the digital platform, always globalized, always asynchronous. Development is radically uneven and the reserve army of capital is on the march.

Print accedes to the pearlescent screen of flicks that learn over time to talk via the voice-over and via characters who are always acting. Bogart, McMurray, Stanwyck, Welles, Nichols, Pitt, Clooney, Davis, and Sarandon. Ingrid Bergman is still waiting in the fog with her incomparable hat. Directors and producers are invisible behind the scenes, plotting the angles of the shots and deciding how the money will work. It's all happening in the background as the war winds down and America winds up.

Fast forward.

Global Noir is a casino with neon signs and enormous LED screens flickering across the face of the city of dreams disappearing into the foreclosures of the Nevada desert or across the face of the City of Dreams rising from reclaimed land in Macau. Signs flicker in the night. L.A. Noire is a Rockstar video game. The Lady Noire Affair, by Dior, stars Marie Cotillard who is stunning in her perfectly painted lipstick in Paris, New York, Shanghai, and London, each aligned with a different color but always with a handbag providing object constancy, a commodity to fetishize. "Who knows what's inside that bag?" she asks. We all know the answer to that.

Global Noir is here to stay. In this cluster of essays, Patrick Blaine explores the function of detectives in post-dictatorial spaces, such as in the "labyrinthine Bío-bío market in Santiago... a collecting point for detritus of contemporary life in the capital." Fabrizio Cilento examines Saviano, Garrone, and the infoldings of criminality into the world capitalist system, such as in Scampia, the "largest open-air drug market in the world." Rick Dolphijn enters into the noir of Murakami's inventions that reflect nothing, but, instead, open into a hall of broken mirrors in which we learn about the "true liberation of the dark." Robert Peckham dives into historical labyrinths that lead nowhere, and that, in turn, become global cities "haunted by the specter of pandemics." And Tim Simpson does gangsters, the grind of Poseidon's casino, and the lotto education of the Chinese consumer in the SAR of Macau.

There is from the Southern Cone across the Americas and Europe to the Chinese littoral, a globalization at work that is leaving visible fractures from the fracking currents of the boom and bust of capital, a long wave that smells like money, smells like work, smells like corruption, smells like the thought of art.

Watch out, then. Be careful crossing the road or turning the next corner. Money for nothing and the world-city on the prowl. Be careful what keys you stroke, what kicks you get. There's always a kick-back and you're being tracked.

Pop. Goes the weasel. 